\title{
PERSON CASE CONSTRAINT EFFECTS IN POLISH COPULAR CONSTRUCTIONS
}

\author{
ANNA BONDARUK \\ Department of Theoretical Linguistics \\ Institute of English Philology \\ John Paul II Catholic University of Lublin \\ Al. Racławickie 14 \\ 20-950 Lublin \\ Poland \\ bondaruk@kul.lublin.pl
}

\begin{abstract}
The paper examines two patterns found in one type of copular constructions in Polish, i.e., those containing the verbal copula być 'be' and the pronominal copula to. In the first pattern the verb byc 'be' agrees with the second, postverbal element, not with the first one, while in the other 1st and 2nd person pronouns are banned from appearing as the first elements in to być copular clauses. It is argued that these apparently unrelated patterns are amenable to a uniform analysis couched within the minimalist approach to the Person Case Constraint (henceforth, the PCC). This approach crucially relies on the application of multiple Agree and the assumption that in Polish, just like in other languages, T probes separately for person and number. It is argued that in both patterns under consideration $T$ probes the first DP for person and the second one for number and gender, which accounts for agreement with the second element in the first pattern. If the first DP is 1st or 2nd person, it values the person feature of T as 1st or $2 \mathrm{nd}$ and this is responsible for a person clash if the second DP is marked for 3rd person, which accounts for the second pattern. The analysis offered predicts that the two DPs in to być clauses must match in person. It is shown that this prediction may turn out to be problematic in the light of the fact that identity statements and inverted copular sentences allow person mismatch. It is argued that although they seem to be problematic in fact neither in the former nor in the latter the mechanism underlying the PCC effect, i.e., multiple Agree, is operative, but for a different reason. Equatives are analysed along the lines proposed by Perelstvaig (2001; 2008) for Russian and Italian by Moro (1997; 2006), i.e., they are treated as bare small clauses which lack a label unless the second DP is internally merged with the bare small clause and thus provides it with a label (DP). As a result of this movement, the moved DP is closer to the probe T than the other DP, which blocks multiple Agree. In inverted copula sentences, on the other hand, parallel probing by $T$ and $C$ applies, which forces the movement of the inverted element to Spec CP and thus makes it unavailable to Agree with T.
\end{abstract}

Keywords: multiple Agree, equatives, specificational clauses, predicational clauses, double object constructions 
Polish copular constructions have been extensively studied in the recent literature. The works available have focused either on the typology and syntactic characteristics of the structure in question (cf. Wiśniewski 1990; Rutkowski 2006; Citko 2008) or on certain constraints governing the use of these sentences (cf. Bogusławski 2002; Hentschel 2001; LindeUsiekniewicz 2007). This paper aims to make a contribution of the latter kind, although some typological and structural remarks will turn out to be indispensable, as well.

The patterns to be analysed in this paper have been cursorily mentioned in some of the sources cited above, but they have not received any analysis so far, nor have they been subject to any systematic scrutiny. The problem to be examined here relates to two agreement patterns observed in a specific type of copular sentences, i.e., the ones with the so-called pronominal copula to and the verbal element być 'be.. In the first pattern the verb agrees with the second, not with the first $\mathrm{DP},{ }^{2}$ linked by the pronominal copula to, as illustrated in (1), where the verb agrees with the neuter DP marzenie każdego młodego człowieka 'a dream of every young man'. In the second pattern the 1st or 2 nd person pronoun, in contradistinction to the 3rd person pronoun, is banned from appearing in the relevant type of clause, as can be seen in (2). ${ }^{3}$

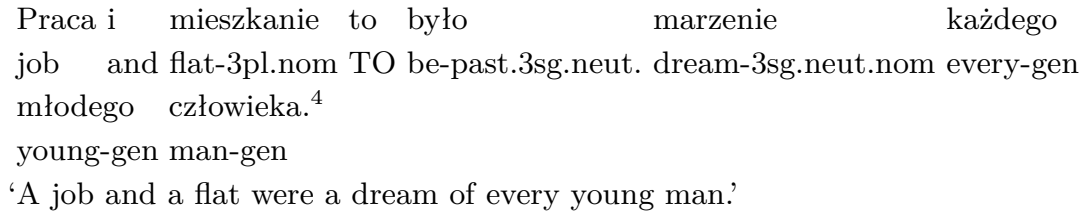

${ }^{1}$ The verb be is regularly omitted in the present tense, yielding the sentences with just the pronominal copula to, as in (2). This issue receives a lot of attention in section 1.

${ }^{2}$ Although the symbol DP is used throughout the paper instead of NP, it is meant to bear no theoretical significance and only stands for any kind of nominal expression.

3 The pronominal copula to is glossed here as just TO.

${ }^{4}$ The following abbreviations are used throughout the paper: abs =absolutive, acc $=$ accusative, $\mathrm{cl}=$ clitic, dat $=$ dative, fem $=$ feminine, gen $=$ genitive, instr $=$ instrumental, $\operatorname{masc}=$ masculine, neut $=$ neuter, nom $=$ nominative, $\mathrm{pl}=$ plural, pres $=$ present, refl $=$ reflexive, $\mathrm{sg}=$ singular, $\mathrm{tm}=$ theme marker, vir $=$ virile, $1=$ first person, $2=$ second person, $3=$ third person, $v \mathrm{D}=$ auxiliary assigning absolutive + dative. 
(2) *Ja /*ty /on to dyrektor.

I-1sg you-2sg he-3sg TO manager

'I/you/he am/are/is a manager.'

A thorough examination of these patterns makes them amenable to an analysis based on the Person Case Constraint (PCC) and this line of analysis is pursued in the paper. It is argued that the PCC, understood as "a requirement that certain types of DP be 3rd person" (Richards 2005, 383), and analysed in terms of multiple Agree, where one probe $\mathrm{T}$ enters Agree with the two DPs linked by to and probes each of them for a different $\varphi$-feature, either person or number/gender, along the lines suggested by Rezac (2008), can account for the two patterns in a uniform way. Since T first undergoes person agreement with the first DP, it is the second DP that determines number and gender in to być clauses, as can be seen in (1). Also, T having entered Agree in person with the first DP cannot agree with the second DP whose person feature is different from that of the first DP. As a result, sentences in which the two DPs do not match in person are predicted to be ungrammatical, as is the case in (2).

However, the requirement that the two DPs must match in their person feature in to być clauses may seem to be problematic in the light of the sentences such as (3) and (4).

(3) Ja to ty.

I-1sg.nom TO you-2sg.nom

'I am you.'

(4) Dyrektor to ja.

manager-3sg TO I-1sg

'I am a manager.'

In the sentences above the two elements linked by to do not match in person feature but the resulting structures are still perfectly licit. It is argued that sentences like (3) and (4) do not constitute counterexamples for the analysis proposed here, as sentence (3) is equative and (4) is specificational, which makes them different from sentences in (1) and (2), which represent predicational structures. An attempt is made to analyse equatives along the lines proposed for Russian by Pereltsvaig (2001; 2008) and for Italian by Moro (2006), while specificational clauses are dealt with by appealing to feature inheritance and parallel probing by $\mathrm{T}$ and $\mathrm{C}$ of Chomsky (2008). 
It is also noted that Polish does not seem to show PCC effects in the original context for which the constraint has first been observed, namely in the double object construction. It is argued that this fact does not pose a threat for the analysis proposed here, as Polish double object constructions are not derived by means of multiple Agree, a mechanism responsible for the PCC cross-linguistically.

The paper is structured in the following way: section $\mathbf{1}$ offers a brief outline of Polish copular constructions in general, together with their syntactic properties, section $\mathbf{2}$ introduces the patterns to be analysed in the paper, section $\mathbf{3}$ provides an analysis of the patterns under scrutiny, section 4 points out some counterexamples and suggests ways of handling them, and finally, the last section contains the summary and conclusions.

\section{Polish copular constructions-An overview}

This section provides a brief introduction to the typology and structure of Polish copular constructions. Due to space limitations, it only mentions those properties of the structure under consideration that are relevant in the further parts of the paper.

According to Citko (2008), Polish exhibits three types of copular sentences, each of which is exemplified below:

(5) Marek jest dobrym lekarzem.

Mark-nom is good-instr doctor-instr

'Mark is a good doctor.'

(6) Marek to dobry lekarz.

Mark-nom TO good-nom doctor-nom

'Mark is a good doctor.'

(7) Marek to jest dobry lekarz.

Mark-nom TO is good-nom doctor-nom

'Mark is a good doctor.'

The first type, illustrated in (5), contains a verbal copula być 'be', which can be followed not only by DPs, as in (5), but also by APs or PPs. The second type, as in (6), exhibits the so-called pronominal copula to, which links only identical elements, typically DPs. The final, third type combines both copula expressions in one structure, as can be seen in (7). 
It is worth noting that the DP following the copula być 'be' is marked for instrumental case, whereas to links two DPs in nominative case only, as is made clear by (6). The latter situation is also attested in the so-called dual copula clauses (Citko 2008, 263), as shown in (7).

Although Citko opts for three types of copular sentences in Polish, it seems to be possible to subsume types 2 and 3 under one category. This is indeed the stand taken by Rutkowski (2006) and Linde-Usiekniewicz (2007). One argument in favour of this claim relates to the fact that to and to być clauses do show analogous syntactic properties, as has been demonstrated by the data above. Also, it seems that to clauses represent a variant of to jest clauses resulting from omitting the verb jest, which is a fairly frequent process and what is more, simple to clauses are considered to sound more natural than to jest clauses, compare the following:

(8) Marek *(to) (jest) dobry lekarz.

Mark-nom *(TO) (is) good-nom doctor-nom

'Mark is a good doctor.'

The above sentence shows that to is always obligatory, whereas byc' 'be' can be omitted in the present tense. If, on the other hand, być 'be' is inflected for some other tense, i.e., past or future, it cannot be dropped, and consequently, to must be followed by the verb być 'be', as confirmed by (9) and (10).

(9) Marek to *(był) dobry lekarz.

Mark-nom TO *(was) good-nom doctor-nom

'Mark was a good doctor.'

(10) Marek to *(będzie) dobry lekarz.

Mark-nom TO *(will-be) good-nom doctor-nom

'Mark will be a good doctor.'

The data provided above clearly indicate that the verb być 'be' can be dropped only in the present tense, but not in the past, as in (9), or in the future, as in (10).

It follows from Citko's typology of copular sentences in Polish that to copular clauses exist only in the present tense, while in the past and future, they require the relevant form of the verb być 'be' to co-occur with to. This is clearly uneconomical and unjustified in the light of the arguments presented above. Therefore it seems more advantageous to assume that there are two, not three, types of copula sentences in Polish, 
namely the sentences with być 'be' and those with both to and być 'be'. In the latter type być 'be' is regularly dropped in the present tense, yielding simple to clauses.

As regards interpretation, the verbal copula sentences, as in (5), typically convey a predicational relation, whereby the property denoted by the element following być 'be' is predicated of the subject. The interpretation of the other type of copular sentences is more complex. Citko (2008) notes that to and to być clauses can convey a predicational relation, as in (6) or (7) above, but also identity, as can be seen in (11) and (12):

(11) Kardynał Ratzinger to Papież Bendykt XVI.

Cardinal Ratzinger TO Pope Benedict XVI

'Cardinal Ratzinger is Pope Benedict XVI.'

(12) Kardynał Ratzinger to jest Papież Bendykt XVI.

Cardinal Ratzinger TO is Pope Benedict XVI

'Cardinal Ratzinger is Pope Benedict XVI.'

Moreover, Citko notes that to and to być sentences, unlike the clauses with być 'be' alone, can have specificational interpretation. ${ }^{5}$ The contrast is shown in (13) and (14) below.

(13) *Najlepszy lekarz jest Markiem.

best-nom doctor-nom is Mark-instr

'The best doctor is Mark.'

(14) Najlepszy lekarz to (jest) Marek.

best-nom doctor-nom TO (is) Mark-nom

'The best doctor is Mark.'

To sum up, the inventory of Polish copular clauses has been grouped into two types, one containing just the verb być 'be' and the other featuring both to and być 'be'. It has been mentioned that both these types can be associated with a predicational interpretation. However, the specificational and identity interpretation is an exclusive property of copular clauses containing both to and być 'be' (cf. footnote 5).

${ }^{5}$ The copula clauses with być 'be' can have specificational interpretation only if the instrumental-case marked DP is fronted, as in (i).

(i) Najlepszym lekarzem jest Marek.

best-instr doctor-instr is Mark-nom

'The best doctor is Mark'

Acta Linguistica Hungarica 59, 2012 


\section{Agreement patterns in Polish copular clauses}

Having presented the basic properties of Polish copular constructions, let us now turn to the very core of this paper, namely the agreement patterns found in the structure examined. Here again, the difference can be noticed between być sentences and those containing both to and być in that the former always show a full agreement in $\varphi$-features with the subject, whereas the latter exhibit agreement with the second element, i.e., the one following być 'be'. The contrast is captured in (15) and (16) below.

(15) Suchocka

była premierem.

Suchocka-3sg.fem.nom be-past.3sg.fem. the Prime Minister-3sg.masc.instr

'Suchocka was the Prime Minister.'

(16) Suc

$\begin{array}{lll}\text { Suchocka } & \text { to był } & / * \text { była } \\ \text { Suchocka-3sg.fem.nom TO be-past.3sg.masc } / \text { be-past.3sg.fem }\end{array}$

premier. ${ }^{6}$

the Prime Minister-3sg.masc.nom

'Suchocka was the Prime Minister.'

In (15) the copula verb agrees in its $\varphi$-features with the feminine subject Suchocka, whereas in (16) the verb być 'be' agrees with the masculine DP premier 'the Prime Minister' and it cannot agree with the feminine DP Suchocka. ${ }^{7}$ These two sentences also show that the subject and the predicate in Polish do not have to agree in gender features.

Another instance of to być clauses which confirms the conclusion drawn above is provided in (17) (example (1), repeated for convenience).

(17) Praca i mieszkanie to było marzenie każdego job and flat-3pl.nom TO be-past.3sg.neut. dream-3sg.neut.nom every-gen młodego człowieka.

young-gen man-gen

'A job and a flat were a dream of every young man.'

${ }^{6}$ Sentence (16) is grammatical when the verb byt 'was' agrees with the masculine DP premier 'Prime Minister'. The form byta is grammatical in (16) only when it does not represent the past tense form of verb być 'be' but stands for the adjective 'former', i.e., Suchocka to byla premier means 'Suchocka is a former Prime Minister', which is irrelevant for our discussion.

${ }^{7}$ Polish has grammatical gender and therefore it seems justified to claim that gender is a formal feature, on a par with person and number in this language. 
In (17) there is a clear mismatch between the two elements appearing in the to być clause as regards number, the first element is in the plural, while the second is in the singular. The agreement in $\varphi$-features is, once again, with the second element.

Let us now turn to another pattern, much less frequently mentioned in the literature. The pattern in question relates to the occurrence of first and second person pronouns in to być clauses. Compare the following:

(18) * Ja /*ty to dyrektor.

I-1sg /you-2sg TO manager

'I/you am/are a manager.'

$(19) * \mathrm{My} /{ }^{*}$ wy $\quad$ to dyrektorzy.

we-1pl/you-pl TO managers

'We/you are managers.'

The sentences in (18) and (19) above clearly indicate that neither the singular nor the plural 1st or 2nd person pronoun is allowed in copular constructions with to. In this way the 1st and 2nd person pronouns clearly contrast with 3rd person ones, as can be seen in (20) and (21) below.

(20) On to dyrektor.

he-3sg TO manager

'He is a manager.'

(21) Oni to dyrektorzy.

they-3pl TO managers

'They are managers.'

The issue why there should be this kind of contrast between 1st and 2nd person pronouns on the one hand and 3rd person pronouns on the other hand is the major concern of this paper. As has already been noted, however, there are some exceptional cases where the ban on 1st and 2nd person pronouns in to być clauses is not respected, compare the equative sentence in (3) above and the specificational one in (4).

\section{An analysis of the agreement patterns found in to być clauses}

In this section an emphasis will be laid on the two patterns described in section $\mathbf{2}$, namely agreement in $\varphi$-features with the second element in $t o$ 
być clauses (cf. (16)-(17)), and the incompatibility of 1st and 2nd person pronouns with the copular structure containing to (cf. (18)-(19)).

\subsection{The Person Case Constraint}

At first glance it may seem that the two patterns under scrutiny do not have much in common, as the first pattern relates to the second element of the to być structure, while the second one concerns the first element. However, under closer examination they turn out to be amenable to an analysis of the same kind. The analysis that will be offered here is based on the Person Case Constraint (PCC), which is a universal condition regulating the distribution of marked person features in certain contexts. The constraint was first examined in the generative framework by Perlmutter (1971), and its detailed scrutiny is provided by Bonet (1991). The constraint specifies that in combinations of a direct and indirect object, both of which are phonologically weak, the direct object may not be 1st or 2nd person (ibid., 177). ${ }^{8}$ The PCC effects are visible in the following examples from French and English, respectively:

(22) (a) Je le lui te ai présenté.

I him-3sg.acc /*you-2sg.acc her-3sg.dat have presented

'I introduced him/*you to her.'

(Béjar-Rezac 2003, 49)

(b) I showed them it/*you/*me ['you'/'me' = weak] (Richards 2008, 143)

These data clearly indicate that in the double object configuration a phonologically weak direct object cannot be 1st or 2nd person in the presence of the phonologically weak 3rd person indirect object.

The PCC is attested in the double object construction in a wide range of typologically unrelated languages such as French, English, Greek, Swiss German, Basque and Georgian (Anagnostopoulou 2003; BéjarRezac 2003). However, it does not seem to be operative in the double object construction in Polish, as can be seen in the following data:

8 The exact formulation of the PCC, provided by Bonet, is reproduced in (i) below:

(i) Person-Case Constraint (PCC) If DAT then ACC-3rd.

(Bonet 1994, 36)

Acta Linguistica Hungarica 59, 2012 


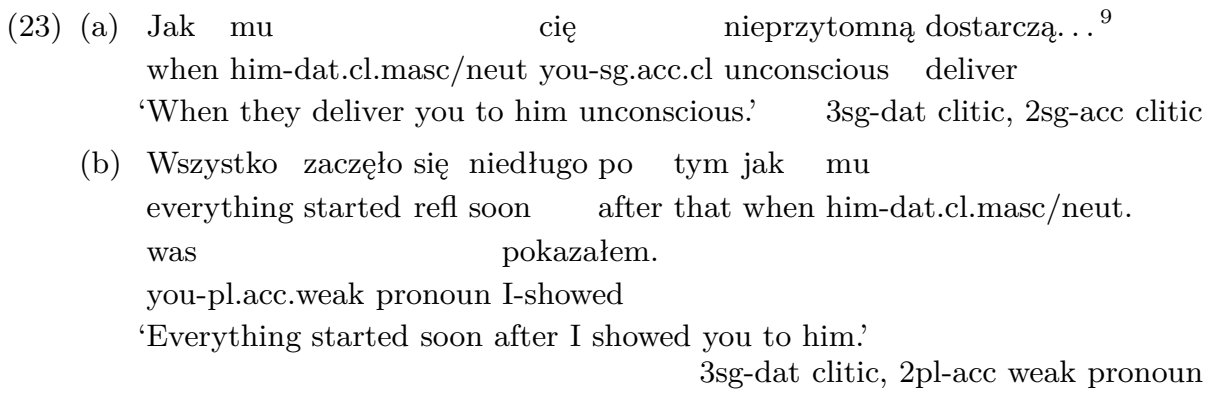

Example (23a) above shows that a combination of a dative 3rd person clitic and an accusative 2nd person clitic is perfectly licit in Polish double object constructions, while (23b) is fully grammatical with a combination of a dative $3 \mathrm{rd}$ person clitic and an accusative 2 nd person weak pronoun. The fact that the PCC does not hold in Polish double object constructions is problematic for the analysis of the two agreement patterns carried out in this paper, couched within the minimalist approach to the PCC. The possible reasons why the constraint is inoperative in Polish in the classical context where is should apply will be examined in section 4.1.

Since it bans 1st and 2nd person pronouns in certain configurations, the PCC seems to have a potential to account for the incompatibility of 1st and 2nd person pronouns with to być clauses in Polish (cf. (18)-(19)). However, our analysis must be somehow modified so as to cover not just the double object structures (which are the primary environment for the PCC to apply) but also the copular constructions in question, and to make it applicable not only to clitics but also to other nominal expressions. In fact, in the literature a number of proposals can be found as to how the PCC can be extended to apply to structures other than the double object configuration and to nominal expressions in general, including strong pronouns, not just clitics. The structures whose analysis has been dealt with in terms of the (somehow modified) PCC include, among others, (1) dative experiencer structures with an absolutive theme in Basque (Rezac 2008), (2) Icelandic applicative unaccusatives (Boeckx 2000; Anagnostopoulou 2003), (3) ay-inversion and long distance extraction in Tagalog (Richards 2005), (4) some experiencer Spanish structures with dative subjects and nominative objects (Rivero 2004), and (5) English existential expletive structures (Richards 2008). Some of these structures are illustrated below:

9 The data in (23) come from the National Corpus of the Polish Language (http://nkjp.uni.lodz/pl).

Acta Linguistica Hungarica 59, 2012 
(24) $* \mathrm{Ni}_{i} \quad$ Itxaso-ri $j_{j}$ gustatzen $\mathrm{n}_{i}$-a-tzai-o ${ }_{j}$.

I-abs Itxaso-dat liking 1-tm-rD-3

'Itxaso likes me'

Basque (Rezac 2008, 63)

(25)*Henni leiddumst við

she-dat was-bored-by-3pl us-nom

'She was bored by us.'

Icelandic (Anagnostopoulou 2005, 205)

(26)*A Ana nos le olvidamos nosotros.

Ana-dat we-refl cl-dat forgot-1pl we-nom

'Ana forgot us.'

Spanish (Rivero 2004, 496)

In sentence (24) the absolutive phrase is 1st person in the presence of the dative 3rd person DP, and the structure is unacceptable; Rezac (2008) notes that it becomes licit only if the 1st person DP is replaced by a 3rd person DP. In the Icelandic example (25), the ungrammaticality results from a combination of a $3 \mathrm{rd}$ person dative pronoun and a 1st person nominative pronoun; the structure is acceptable if the 1st person nominative pronoun is replaced with a 3rd person one (cf. Anagnostopoulou 2005, 205). Finally, the Spanish sentence in (26) is illegitimate as it contains a 3rd person dative DP with a 1st person nominative DP, and as Rivero (2004, 496) observes, it can become grammatical only if the nominative phrase is 3rd person. Since they show a ban on a 1st person DP in the presence of a 3rd person one, all the sentences in (24)-(26) have been analysed in terms of the broadly understood PCC, i.e., the constraint being operative not only in the double object construction and affecting not only clitic pronouns.

In fact the broad formulation of the PCC will be adopted in this paper. We follow Richards $(2005,383)$, for whom PCC is "a requirement that certain types of DP be 3rd person". As we will see in section 3.3, this requirement is broad enough to account for the Polish agreement facts analysed here.

The PCC has been approached in the literature either from the point of view of morphology (Bonet 1991; 1994; Albizu 1997; Haspelmath 2004, among others) or syntax (for instance, Anagnostopoulou 2003; BéjarRezac 2003; Rezac 2008; Richards 2008). The analysis offered in this paper belongs to the latter camp. Within the Minimalist Program of Chomsky (2000; 2001), the PCC is commonly derived in terms of multiple Agree (Hiraiwa 2002), where one probe targets two goals. 
One implementation of the idea that it is multiple Agree that underlies the PCC effects is described in (27), quoted after Rezac $(2008,68)$.

(27) Case/Agree account of the Person Case Constraint

(i) The PCC arises when two or more goals, X and Y, Agree with the same Case locus.

(ii) Split Agree: $\mathrm{H}$ has person and number probes that can seek to Agree independently.

(ii) Locality and intervention: dative X prevents H-Y person Agree by relativized minimality, but it permits $\mathrm{H}-\mathrm{Y}$ number Agree.

(iv) The Case Filter: The $\varphi$-features of DPs need Case. 1st/2nd person features need person Agree for Case licensing, while for 3rd person DPs, viewed as possessing number alone, number Agree suffices. DPs with inherent Case such as dative are licensed by it.

(Rezac 2008, 68)

The analysis outlined above, based on Rezac (2008), makes a number of crucial assumptions. First of all, person and number are treated as separate probes (cf. (27ii)). Secondly, dative DPs intervene in Agree for person, but not in Agree for number (see (27iii)). Thirdly, 1st and 2nd person DPs are different from 3rd person DPs in that they have a person feature which must be licensed via Agree in order to bring about their Case valuation (see (27iv)). All of these assumptions figure not just in Rezac's (2008) account, but also in other works, such as Anagnostopoulou (2003), Béjar-Rezac (2003) and Richards (2008).

Before turning back to Polish data, let us first check how Rezac's account, outlined above, works for French double object constructions, as in (28) below.

(28) Lucille la $\quad / *$ nous leur présentera.

Lucille her-acc $/{ }^{*}$ us-acc them-dat will-introduce

'Lucille will introduce her $/^{*}$ us to them.'

(Rezac 2011, 156)

In this case the relevant probe is $\mathrm{v}$ which has two possible goals, the dative and the accusative clitic (cf. (27i)). v probes separately for person and number (cf. (27ii)). The dative is above the accusative and it is 3rd person, which for Rezac (2008) means [-person] (cf. (27iv)). The dative clitic in (28) constitutes an intervener between $\mathrm{v}$ and the accusative clitic and hence bars person agreement between them (cf. (27iii)). Consequently, in (28) only the 3rd person accusative clitic is possible, as it lacks a person feature altogether, and therefore does not undergo person agreement with v. Rezac does not offer any structural representation for sentences like 
(28) above, consequently, only its schematic representation is provided based on the discussion Rezac $(2008,92)$ carries out in relation to PCC repair strategies in French (this topic in analysed in detail in Rezac 2011).

(29) S T v [ApplP IO Appl [vP V DO]] $\underbrace{10}$

Out of Rezac's (2008) assumptions provided in (27) we will adopt (27i) and (27ii) without any modifications, whereas assumption (27iii) will be modified so as not to make reference to a dative intervener; in fact the claim will be made that any $\mathrm{X}$ counts as an intervener for the person Agree between H and Y. Finally, assumption (27iv) has no role to play in the analysis of two agreement patterns in Polish copular constructions to follow.

Before demonstrating the validity of the PCC analysis based on multiple Agree for the Polish agreement facts under consideration, let us make clear what sort of structure is associated with the relevant copular construction. This is the main concern of section 3.2.

\subsection{The structure of to być clauses}

The structure of to być clauses that we will adopt in this paper implements Citko's (2008) proposal. Citko argues that in the structure analysed, the predication relation is syntactically encoded by a functional head which she calls $\pi$. This head in this kind of structure is defective in that it lacks $\varphi$-features altogether. Since $\pi$ is deprived of any $\varphi$-features, it cannot value any Case. Moreover, Citko draws a parallelism between $\pi$ and coordinators, since both of them can link just identical categories. The structure Citko puts forward for to być clauses is shown in (30).

In the structure in (30) to is $\mathrm{T}$, while być functions as a $\pi$ head. $\mathrm{T}$ has a full set of $\varphi$-features, in contradistinction to a defective $\pi$, and it establishes an Agree relation with both DPs, thereby it values their Case feature as nominative. $\mathrm{T}$ also possesses an EPP feature which triggers movement of the closest DP to Spec, TP, deriving a surface word order. Finally, there occurs a covert movement of the verb być to the word to in $\mathrm{T}$, since the tense inflection is normally realized on the verb. For Citko, to is a kind of expletive copula, deprived of any tense features, until the verb has adjoined to it at $\mathrm{LF}$.

${ }^{10}$ IO stands for an indirect object, DO represents a direct object, and S corresponds to a subject.

Acta Linguistica Hungarica 59, 2012 
(30) Warszawa to jest stolica Polski.

Warsaw TO is capital of-Poland

'Warsaw is the capital of Poland.'

(Citko 2008, 292)

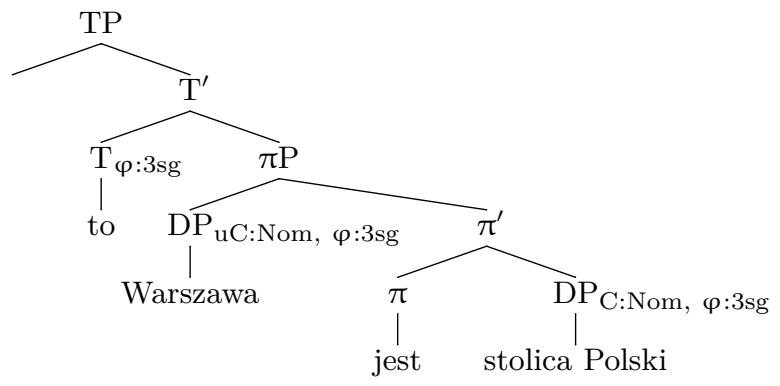

Citko's analysis seems to get additional support from sentences like (31) below:

(31) *Nikt to nie jest student.

nobody TO not is student

'*Nobody is not a student.'

The sentence in (31) is unacceptable and Citko's analysis is capable of accounting for this fact. If, as argued by Witkoś (1998), the negative marker nie 'not' in Polish is a prefix on the verb, then the ungrammaticality of (31) follows from the fact that negation, being a part of the verb and occupying $\pi$, does not c-command and hence does not license the negative word nikt 'nobody', which originates in Spec, $\pi \mathrm{P} .{ }^{11}$

The structure proposed by Citko has a lot of advantages in that it can easily account for the double nominative found in to być structures as well as for the fact that to can link only identical elements (for a thorough evaluation of her analysis cf. Bondaruk 2010) and therefore, it will be adopted in our analysis of the two agreement patterns carried out in the next section.

\subsection{PCC analysis of the two agreement patterns}

We are now equipped with all the necessary components to be able to come up with an analysis of the two agreement patterns mentioned in

${ }^{11}$ Polish is a negative concord language and therefore to be licensed a negative word must be c-commanded by a negative element.

Acta Linguistica Hungarica 59, 2012 
section 2. However, before embarking on the analysis itself, let us make a few observations concerning Polish agreement which are relevant for further discussion. First of all, in Polish the verb generally agrees with the subject in person, number and gender, which jointly form a set of $\varphi$-features in this language. It is also worth noting that in Polish in the plural there exists just a two-gender system, virile and non-virile, unlike in the singular, where all the three genders, masculine, feminine and neuter, are attested.

Let us now, for the sake of clarity, repeat the relevant agreement data. Compare:

(32) Ci mężczyźni to była drużyna piłkarska. these men-3pl.virile.nom TO be-past.3sg.fem team-3sg.fem.nom football-sg.fem 'These men were a football team.'

(33) *Ja $/ *_{\text {ty }} \quad$ to dyrektor.

I-1sg /you-2sg TO manager

'I/you am/are a manager.'

Sentence (32) illustrates the fact that in to być clauses agreement in $\varphi$ features is always with the second element. Sentence (33) (example (18), repeated for convenience), on the other hand, illustrates the ban on 1st and 2nd person pronouns in to być copular sentences.

Let us start by deriving sentence (32). We follow assumptions (i) and (ii) listed in (27) above and propose that there are two nominal expressions which compete with each other for the head to value their Case feature (see (27i)). In fact a single possible probe for the two goals is $\mathrm{T}$, which probes separately for person on the one hand, and number and gender on the other (see (27ii)). First T establishes Agree with the first DP and has its person feature valued as 3rd and as a byproduct of this agreement it values the Case of this DP as nominative. Then $\mathrm{T}$ probes further in order to have its number and gender valued and it establishes the second Agree relation with the second DP, whereby it has its number and gender features valued as singular feminine and it values the Case of the DP as nominative. This derivation is schematized in (34) below.

(34) T.

DP1 DP2

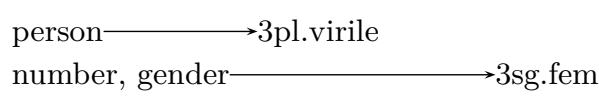


Since the first DP in (34) has not only a person, but also a number and gender feature, we must assume that $\mathrm{T}$, probing separately for person and number/gender, first probes for person and has it valued by DP1 and only afterwards does it probe for number and gender. Consequently, T must bypass the number and gender features of DP1, having established with it a person agreement. It seems, then, that there is no 'real' multiple Agree, as T agrees with each DP for a different $\varphi$-feature.

It seems to follow from the analysis presented so far that it is incorrect to claim that the verb in to być structures agrees in $\varphi$-features with the second element. In fact it is more adequate to say that the verb agrees in number and gender with the second element, while it agrees in person with the first one. This 'split agreement' account might get support from the fact that normally $\varphi$-feature agreement in Polish is determined by a nominative DP. Since in to być clauses there are two nominative DPs, each of them is expected to have some role to play in determining the agreement and thus a form of the verb. Consequently, the split agreement suggested above seems to be the expected scenario. Actually to być clauses are the only type of structure in Polish with a double nominative, and therefore it should not be at all surprising that they show a distinct behaviour as regards agreement.

The conclusion drawn in the previous paragraph gains additional support from an analysis of the data like (33) above. As has been argued in section $\mathbf{l}$ (see example (8)), the copular sentences with just to are derived from those containing both to and być 'be'; where the latter is regularly omitted in the present tense, as can be seen in (35).

(35) * Ja /*ty to (jestem /jesteś) dyrektor.

I-1sg /you-2sg TO (be-pres.1sg /be-pres.2sg) manager-nom

'I/you am/are a manager.'

In (35) (and in (33)) once again we have two goals $j a$ 'I' and dyrektor 'manager' and a single probe T. Also here T probes separately for person, and number. No gender agreement surfaces in 1st and 2nd person verb forms in the present tense. Since the closest goal is $j a$ ' $I$ ', as a result of the Agree operation $\mathrm{T}$ has its person feature valued as 1st, and as a consequence it values the Case feature of the pronoun as nominative. Then, $\mathrm{T}$ targets the second DP and probes for its number and consequently it values the Case feature of the second DP as nominative as well. The unacceptability of (35) and (33) follows from the person mismatch, since T, having entered Agree with the 1st person pronoun $j a$ 'I' 
has its person feature valued as 1st, and therefore it cannot enter Agree with the second goal which is 3rd person, without giving rise to a person feature clash. This scenario is illustrated in (36) below.

(36) T......DP1 ......DP2

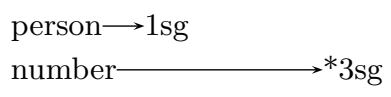

(35) (and also (33)) are ungrammatical unlike (32), where the person feature on both goals is the same, i.e., 3rd, and consequently, no mismatch arises. Although in (32) DP1 is plural and DP2 is singular, there is no number feature mismatch, because $\mathrm{T}$ at the point of entering the Agree operation with DP1 does not value its number feature (in other words, it skips the number feature of DP1), only person, and therefore its number feature remains unvalued until the second Agree with DP2 has taken place. As a result, the number feature on $\mathrm{T}$ does not clash with the number feature on DP1.

Consequently, the analysis just presented crucially relies on the person match in to być clauses, i.e., the clauses in which DP1 and DP2 have the same person feature are fully grammatical, however, there is no need for the number feature match between the two DPs. This claim gets support from sentences such as (37) below.

(37) Ja to ja, a ty to ty.

I-1sg TO I-1sg and you-2sg TO you-2sg

'I am who I am and you are who you are.'

In (37) to links the pronouns with identical person features and hence these sentences are fully licit, which seems to support the claim that to być clauses require person match between the two linked DPs. However, as has been mentioned at the very outset (cf. examples (3) and (4)), this claim is not entirely true, as there are cases in which person mismatch between two DPs does not render to być clauses ungrammatical. Cases like this are examined in detail in the subsequent section.

\section{Problematic cases}

This section focuses on three issues that are relevant for the analysis offered in the preceding section and which, at first glance, constitute a problem for it. First of all, an attempt will be made to account for the 
fact, noted in section 3.1, that the PCC is inoperative in Polish double object constructions. Secondly, we will turn to sentences such as (3) and (4), which contradict the claim that the two DPs linked by to must have an identical person feature. Finally, the focus will be laid on sentences in which inversion of DP2 has taken place, yielding a grammatical structure despite the person mismatch. The discussion in this section is, of necessity, fairly preliminary and only touches upon a variety of issues that require a separate thorough examination.

\subsection{PCC in Polish double object construction}

The status of the PCC in Slavic languages has been subject to a considerable debate. While there is a general consensus that Bulgarian and Macedonian, languages with verb adjacent clitics, do show PCC effects, languages such as Czech, Polish, Slovene and Slovak, etc., have been treated as lacking PCC effects at all by some linguists (see, for instance, Haspelmath 2004; Migdalski 2006), while some others have found these effects to be operative in these languages as well (cf., for instance, FranksKing 2000; Béjar-Rezac 2003; Sturgeon et al. 2010).

The data provided in (23) in section $\mathbf{3 . 1}$ above show that Polish double object constructions regularly disobey the PCC (cf. also Bondaruk to appear). This seems to be a problem for the analysis just offered. The way out of this problem appears to lie in the analysis of the double object construction in Polish proposed by Citko (2011). Citko (op.cit., 154) argues that the dative case in Polish represents a quirky case which is a combination of an interpretable lexical case and an uninterpretable structural case, both of which must be valued in the course of the derivation. ${ }^{12}$ However, the way these two types of case get valued is different; interpretable case is valued at first Merge, whereas uninterpretable case is valued via Agree. She further argues that Polish double object constructions contain a new functional projection, called a light applicative phrase (applP), distinct from ApplP, which values the uninterpretable case feature of the dative DP, and since it has an EPP feature, it also forces the movement of the dative DP to Spec, applP. Consequently, a sentence like (38), taken from ibid., 139, has the derivation shown in (39).

\footnotetext{
12 The assumption that an interpretable case needs to be valued is a departure from the standard minimalist assumptions.
} 
(38) Jan wysłał Piotrowi książkę.

John-nom sent Peter-dat book-acc

'John sent Peter a book.'

(39)

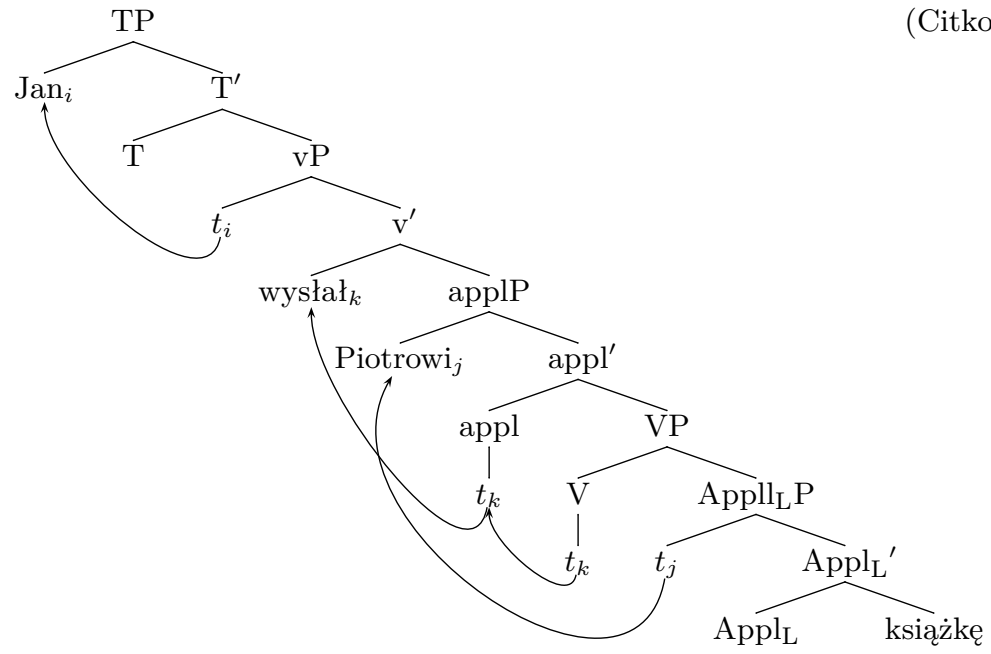

The above structure contains a low applicative phrase $\mathrm{Appl}_{\mathrm{L}} \mathrm{P}$, but also the new projection posited by Citko, i.e., applP. In (39) the dative phrase Piotrowi 'Peter' has its interpretable case feature valued on Merge in Spec, $\operatorname{Appl}_{\mathrm{L}} \mathrm{P}$, and its uninterpretable case feature is valued by the light applicative head, which, thanks to its EPP feature, triggers the movement of the dative DP to Spec, applP. The accusative object, ksiaczke 'book', has its case valued via Agree with v. The dative DP, being inactive, does not intervene in the Agree operation between $\mathrm{v}$ and the accusative DP. ${ }^{13}$ Citko argues that this analysis allows her to account for

13 This assumption seems to be justified for Polish, as the dative experiencer does not block raising in this language, as can be seen in (i), taken from Citko (2011, $150)$.

(i) $\operatorname{Jan}_{i} \quad$ wydaje mi się [ $t_{i}$ być najlepszym kandydatem].

John-nom seems me-dat refl be best-inst candidate-inst

'John seems to me to be the best candidate.'

In this respect Polish differs from Spanish, in which the experiencer dative blocks raising, as can be seen in (ii), quoted after idem.

(ii) ${ }^{*}$ Este $\operatorname{taxista}_{i}$ me parece $\left[t_{i}\right.$ estar cansado].

this taxi-driver-nom me-dat seems be tired

'It seems to me that this taxi driver is tired.'

Acta Linguistica Hungarica 59, 2012 
the fact that only direct objects can passivise in Polish double object constructions. ${ }^{14}$ Since the indirect object has its uninterpretable case feature valued and has moved to Spec, applP, it does not act as an intervener for A-movement of a direct object. Also, the indirect object cannot be passivised as its movement from one case position to another is blocked for economy reasons.

The analysis just presented for objects realized as full DPs can be applied to clitic and weak pronoun objects found in the double object construction in cases such as (40) below (example (23a), repeated for convenience).

(40) Jak mu cię nieprzytomną dostarczą...

when him-dat.cl.masc/neut you-sg.acc.cl unconscious deliver

'When they deliver you to him unconscious.' 3sg-dat clitic, 2sg-acc clitic

Also in this case each object undergoes Agree with a different head, the dative one with appl and the accusative one with v. This makes Polish double object constructions different from those of French, illustrated in (28), where one probe, namely $\mathrm{v}$, targets two goals, i.e., the dative and the accusative DP.

Citko's analysis, just sketched, allows us to explain why Polish lacks the PCC effects in the double object construction. It has been argued in section 3.1, based on data from various languages, that PCC effects generally arise if there are two goals for one probe. The same mechanism of multiple Agree underlying the PCC has been extended to the two agreement patterns found in Polish copular sentences with to and być. On the other hand, following Citko (2011), it has been pointed out that in Polish double object constructions the two object DPs undergo Agree with two distinct heads, the dative one with appl, and the accusative with $\mathrm{v}$. Consequently, the PCC does not hold in the double object construction

14 The contrast between direct and indirect object passivisation is shown in (i) and

(ii) below, taken from Citko $(2011,157)$.

(i) Książka została wysłana Piotrowi.

book-nom became sent Peter-dat

'The book was sent to Peter.'

(ii) *Piotr został wysłany książkę.

Peter-nom became sent book-acc

'Peter was sent a book.'

Acta Linguistica Hungarica 59, 2012 
in Polish, as the mechanism responsible for its emergence is not found in this type of structure. Hence, the fact the PCC does not operate in the Polish double object construction does not seem to invalidate the analysis provided in the previous section, which relies on multiple Agree.

\subsection{To być clauses with person mismatch}

There exist cases in which to can link items whose person features do not match. In the IPI PAN corpus (http://korpus.pl), the following cases of person mismatch have been found:
(41) Ja to Andrzej.
I-1sg.nom TO Andrew-3sg.nom
'I am Andrew.'
(42) Ja to ty. ${ }^{15}$
I-1sg.nom TO you-2sg.nom
'I am you.'

The question is why the sentences in (41)-(42) are perfectly licit although they contain a person mismatch between DP1 and DP2, in contradistinction to sentences like (33) and (35) above. It seems that the difference between the sentences in question lies in their interpretation. The sentences like (33), analysed in terms of the PCC effects, are predicational, i.e., they predicate a certain property of the subject. However, sentences (41)-(42) do not convey a predicational relationship between the two DPs, but rather signal identity (or its lack) between the two DPs and thus they resemble sentences like (11) and (12), provided in section $2{ }^{16}$ They also show a typical property of identity statements, i.e., reversibility of the two DPs, which can be seen in the following example:

${ }^{15}$ Example (42) corresponds to sentence (3), repeated for convenience.

${ }^{16}$ However, the anonymous reviewer notes that true exceptions to the ban on 1st and 2nd person pronouns in to być clauses which are predicational, not equative, are also attested and provides the following sentence:

(i) A ja to pies?

and I TO dog

'Am I a dog?'

The acceptability of this sentence might indicate that the ban on 1st and 2nd person subjects in predicative to być clauses is not absolute in Polish. 
(43) Andrzej to ja.

Andrew-3sg.nom TO I-1sg.nom

'I am Andrew.'

Example (43) is a "reversed" version of (41), and also example (42) has a fully acceptable "reversed" version.

What is more, in a way similar to identity statements, the sentences in (41)-(42) exhibit two DPs that are referential, which sets them apart from predicational sentences like (33), in which only the first DP is referential, while the other, being a predicate, is not. In order to make this difference clear, let us analyse the following data:

(44)*Ja to dyrektor.

I-1sg.nom TO manager

'I am a manager.'

(45) Ja to ten dyrektor.

I-1sg.nom TO this manager

'I am this manager.'

In (44), which is predicational, the second DP is non-referential, which renders this sentence unacceptable. Replacing the non-referential DP with a referential one, as in (45), yields an acceptable structure, which nonetheless has an identity, not a predicational, meaning.

Since the above sentences have an identity interpretation, they seem to call for a structural analysis different from that offered for predicational to być sentences, put forward in section 3.3. In the literature a large number of accounts has been put forward for identity (or equative) structures (cf. Adger-Ramchand 2003; den Dikken 2006), among others). The account that will be adopted here is a slightly modified version of Pereltsvaig (2001; 2008).

She analyses equative sentences, such as (46), in Russian in terms of a bare small clause, provided in (47).

(46) Oleg byl durak.

Oleg-nom was fool-nom

'Oleg was a fool.'

(Pereltsvaig 2001, 16) 
(47)

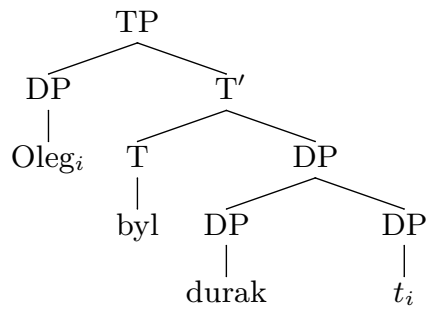

Pereltsvaig notes that copular sentences with the structure in (47) cannot involve a predicational relation between the two DPs, but instead they have an equative (or identity) interpretation. ${ }^{17}$ In other words, "a bare copular sentence is true if and only if the referent of the pre-copular DP and that of post-copular DP are identical" (Pereltsvaig 2001, 183). She further notes that the structure such as (47) is only possible when the two DPs have identical feature bundles, which forces their co-indexation in syntax, underlying their coreference. The coindexation of the two DPs is in itself not unproblematic, as it leads to a violation of Principle $\mathrm{C}$ in cases such as (46). To prevent this, Pereltsvaig resorts to a modified definition of binding, according to which no binding violation takes place if the two DPs are in a mutual c-command relation. The exact formulation of the modified definition of binding is provided in (48) (ibid., 191).

(48) Binding (revised definition)

$\alpha$ binds $\beta$ iff

(i) $\alpha$ and $\beta$ are coindexed and

(ii) at least one copy of $\alpha$ c-commands at last one copy of $\beta$ and

(iii) the lowest copy of $\alpha$ and the lowest copy of $\beta$ do not mutually c-command each other.

In (47) the two DPs mutually c-command each other and hence, in accordance with (48), they do not bind each other and therefore no Principle $\mathrm{C}$ violation arises.

As regards the Case marking in identity statements such as (46), Pereltsvaig considers nominative to be the unmarked form. She notes that this case can be found with two types of nominals, namely: "(i) those

${ }^{17}$ Pereltsvaig argues that Merge can yield symmetrical structures such as the DP in (47) above which then must be converted into asymmetrical structures in order to be linearised at PF in accordance with Kayne's (1994) Linear Correspondence Axiom. 
whose nominative is licensed by a certain syntactic configuration, and (ii) those that need not be marked for case at all" (Pereltsvaig 2001, 213). For her, bare copular sentences constitute the latter set, as the two DPs found in them are not arguments and hence do not need case. For this reason they are associated with the default nominative case.

One more issue that needs to be explained in relation to (47) is why the second DP must move to Spec, TP, even though T has not established any Agree relation with it. Pereltsvaig argues that DP2 moves to Spec, TP to satisfy the EPP feature of T, understood as the uninterpretable Dfeature of T. The question is now why DP2 moves to Spec, TP, not DP1, which is closer to T. Pereltsvaig $(2001,109)$ observes that the movement of DP1 to Spec, TP is blocked, as this would result in a symmetrical structure which would not be linearised at PF (cf. footnote 17).

Let us now try to apply Pereltsvaig's account to Polish sentences like those in (41)-(42). Following Citko (2008), it has been suggested in section 3.2 that in these examples to functions as T. For instance, for (41) we would have the following structure:

(49)

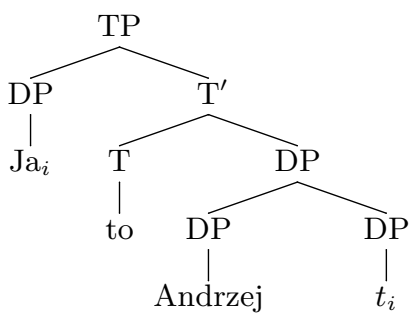

We would have to depart from Pereltsvaig's line of analysis and suggest that the identity interpretation is possible in (49), even though the two DPs do not have an identical set of $\varphi$-features (cf. Citko 2011, 185) for a similar assumption). This seems to be justified, as even in Russian the two DPs can differ in gender, as confirmed by the following sentence from Pereltsvaig $(2008,54)$, where the first DP is feminine and the conjoined second DP comprises two masculine DPs.

(50) Valentina Ivanova - sekretar' gorkoma, i vernyj tovarišč po partii. V. I.-fem secretary-masc city-committee and loyal-masc comrade-masc at party 'Valentina Ivanova is the secretary of the city committee and a loyal party comrade.'

Furthermore, equatives such as (41) can contain not just to, but also być 'be', and the resulting structure is as in (51): 
(51) Ja to (jestem) Andrzej.

I-1sg.nom TO (am) Andrew-3sg.nom

'I am Andrew.'

For those sentences we have to posit the structure containing a $\pi \mathrm{P}$, which is typical for to być clauses (cf. (30) above). Consequently, (51) would have to be associated with the following structure.

$(52)$

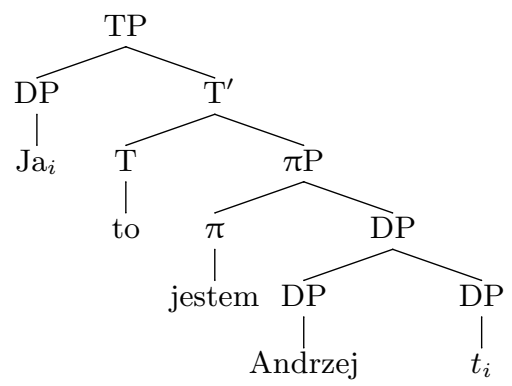

Another question that must be addressed is why multiple Agree cannot target both DPs in equatives such as (52). If multiple Agree were possible in (52), we would run into the problem of why the PCC effects cannot be observed in this type of structure. In Pereltsvaig's analysis neither of the two DPs in equatives undergoes Agree with T. This assumption, however, is problematic for Polish, where the verb clearly agrees with the DP that moves to Spec, TP, as shown in (52) above. This implies that Agree does indeed operate between these two items. An explanation we would like to offer for the ban on multiple Agree in Polish equatives is based on Moro (2006, 2-3), who argues that equatives represent bare small clauses (henceforth, BSC), which, in turn, form the so-called unstable structures, i.e., structures without a label. Moro further argues that one of the DPs from within the bare small clause must be internally merged with it to provide a label for the ultimate structure. When the DP merges with the bare small clause, the resulting structure has a label of the DP. This is schematically represented in (53), taken from Moro (op.cit., 3).

(53) $[\mathrm{DP} \text { DP }[\mathrm{BSC} \text { DP } ¥ \mathrm{PP}]]^{18}$

18 Actually, Moro argues that either of the two DPs can be internally merged with the bare small clause. We stick to Pereltsvaig's original suggestion that it is just the second DP that is internally merged with the BSC. 
If this line of analysis is adopted to the representation in (52), then the resulting structure will be as shown in (54).

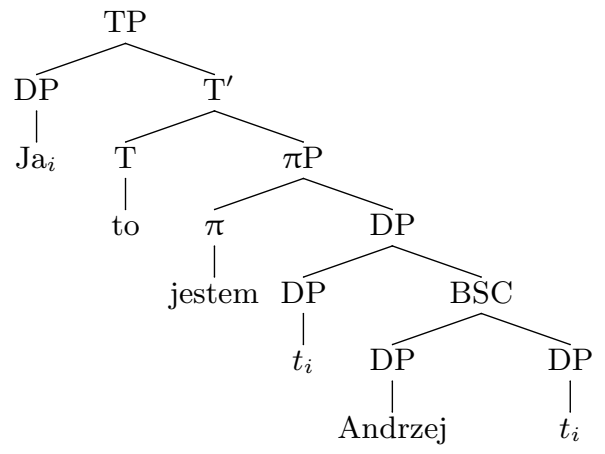

In (54) the two DPs form a structure without a label, i.e., a bare small clause, the second DP is moved (or internally merged) with the bare small clause and thus supplies it with the label DP. The rest of the structure is the same as in (52). We would like to argue that in (54) only the DP that is internally merged with the bare small clause can be targeted by the probe $\mathrm{T}$, as it is closer to $\mathrm{T}$. The pronoun $j a$ ' $\mathrm{I}$ ' in (54) c-commands the other DP, i.e., Andrzej 'Andrew', and unlike in the case of predicative structures such as (30) above, where the two DPs represent either a specifier or a complement of the same functional head, in this case the two DPs are not found in the same projection at all. Therefore the DP Andrzej 'Andrew' is a more distant goal than the pronoun $j a$ ' $\mathrm{I}$ ' and, consequently, it cannot enter Agree with T. Since no multiple Agree applies in equatives like (54), no PCC effects can be attested in this case.

To sum up, Pereltsvaig's (2001) account can be applied to Polish equatives with some modifications. One problematic question it raises concerns feature identity between the two DPs, which has had to be relaxed for Polish in order to capture cases of person mismatch. Also, following Moro (2006), it has been suggested that the second DP from within a bare small clause must be first internally merged with the bare small clause to provide it with a label and, as a result of this movement operation, the moved DP ends up closer to T than the other DP, which excludes the possibility of multiple Agree in equatives. Hence, no PCC effects are expected to arise in this type of structure. All in all, the cases of person mismatch, discussed in this section, clearly represent equative structures which are different from the instances of predication analysed 
in terms of the PCC in section $\mathbf{3 . 3}$, so they do not really pose any threat for our account.

\subsection{Inverted structures}

Person mismatch is also possible in Polish inverted copular structures, as can be seen below:

(55) Dyrektor to ja. ${ }^{19}$

manager TO I-1sg

'I am a manager.'

Sentence (55) clearly shows a person mismatch between the two DPs, but nonetheless is fully grammatical. If we add the verb być 'be' in (55), it clearly agrees with the pronoun, as can be seen in (56).

(56) Dyrektor *(to) (jestem) ja.

manager TO be-pres.1sg I-1sg

'I am a manager.'

Looked at from the point of interpretation, it seems that sentence (55) has a specificational meaning, as it specifies the value for a variable (cf. Akmajian 1979, 162-5), i.e., it specifies who is a manager. Specificational sentences have given rise to a lot of controversy in the literature, and are analysed by some linguists as equatives (see, for instance, HeycockKroch 1999), while others (e.g., Heggie 1988) look upon them as inverse predicational structures. The analysis that we are going to advance for sentences like (55) and (56) is based on parallel probing, proposed in Chomsky (2008) and the assumption that the inverted DP occupies not an A-, but an $\mathrm{A}^{\prime}$-position and hence it does not trigger agreement with the verb być 'to be' in such sentences (cf. (56)). The derivation of (56) is schematized in (57) below:

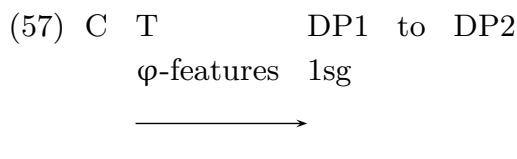

19 This is example (4), repeated for convenience. 
In (57) $\mathrm{C}$ and $\mathrm{T}$ probe in parallel, $\mathrm{T}$ targets the closest goal, i.e., DP1, while C establishes Agree with DP2. We must assume that DP2 has some sort of feature that makes it a potential target for C. A possible candidate for this kind of feature is topic, as DP2 in specificational clauses normally conveys old (or known) information. $\mathrm{T}$ has all its $\varphi$-features valued by DP1, and it cannot target DP2, which has moved to Spec, CP (or some other specialized projection within the split $\mathrm{CP}$ ) to satisfy the edge feature of $\mathrm{C}$ and thus no longer constitutes a possible goal. Subsequently, DP1 moves to Spec, TP to satisfy the EPP feature of T. We would like to suggest that the ultimate word order in which the subject comes last arises as a result of the fact that the subject DP in specificational clauses is associated with focus and as such must appear in the rightmost position in the clause. This position is typical of focused subjects not only in Polish, but also in Russian, as noted by Slioussar (2011). Following her analysis, we would like to suggest that also in Polish focused subjects first move to Spec, TP for EPP reasons and subsequently they undergo information structure related movement to the clause final position. An alternative suggestion would be to claim that the subject remains in Spec, $\mathrm{TP}$, but the material around it, including the VP, undergoes movement (op.cit., 2051). Consequently, sentences like (55) and (56) do not give rise to any person mismatch, as no multiple Agree ever takes place in such cases, as T targets only the first DP; the second DP having moved to the left periphery of the clause, is no longer a possible target. ${ }^{20}$ In this respect our analysis seems to resemble Béjar and Rezac's (2003) and Rezac's (2011) accounts, in which the movement of an intervener to the position where it ceases to be a possible goal voids the PCC effects.

The account just presented runs counter the analyses proposed for English inverse copula sentences by Moro (1997) and Mikkelsen (2005), among others, in which the inverted predicate is taken to occupy the canonical subject position, i.e., Spec, TP, not a left peripheral position as in the analysis sketched above. However, it seems to be possible to adduce some evidence that Polish inverted predicates do not occupy the Spec, TP position. The evidence relates to extraction facts. Let us first note that Moro (1997) observes that there is a contrast as regards extraction from within the second DP in uninverted sentences, as in (58) and inverted structures, as in (59), in English. Compare the following:

\footnotetext{
${ }^{20}$ Since the inverted DP does not enter Agree with T, it has its nominative Case assigned by default.
} 
(58) which riot $_{i}$ do you know a picture of the wall was the cause of $t_{i}$

$(59)^{*}$ which wall ${ }_{i}$ do you think the cause of the riot was a picture of $t_{i}$

As the above data show, wh-extraction is felicitous from within the second DP only in uninverted predicational clauses in English. Moro (1997, 25) notes that similar extraction facts can be observed in Italian. As regards Polish, extraction brings about analogous results, as can be seen in (60a) and (60b), which represent sentences without extraction, and (61a) and $(61 b)$, in which extraction has taken place. ${ }^{21}$

(60) (a) Artykuł o strajku to była przyczyna zamieszek. article-3sg.masc about strike TO was-3sg.fem cause-3sg.fem of-riots 'An article about the strike was the cause of riots.' predicational (uninverted)

(b) Przyczyna zamieszek to był artykuł o strajku. cause-3sg.fem of-riots TO was-3sg.masc article-3sg.masc about strike 'The cause of riots was an article about the strike.' specificational (inverted)

(61) (a) Jak myślisz czego $_{i}$ artykuł o strajku to była przyczyna $t_{i} ?^{22}$ what you-think what article about strike TO was cause 'What do you think an article about the strike was the cause of?' uninverted

(b) *Jak myślisz o $\quad \operatorname{czym}_{i}$ przyczyna zamieszek to był artykuł $t_{i}$ ? what you-think about what cause of.riots TO was article '*What do you think the cause of riots was an article about?'

${ }^{21}$ Long $w$ h-extraction out of finite complements is not freely available in Polish (cf. Willim 1989, 112). Although wh-extraction out of non-finite clauses is possible in Polish, it cannot be applied to to być clauses, as they cannot co-occur with the empty PRO subject, as can be seen (i).

(i) *Marek chce [PRO to być mój przyjaciel].

Mark wants TO be my friend

'Mark wants to be my friend.'

However, the most natural equivalent of English long distance wh-extraction in Polish is shown in sentence (ii), taken from ibid., 113, where the phrase jak myślisz 'what do you think' represents a viewpoint adjunct.

(ii) Jak myślisz co Jan kupi?

what you-think what John will-buy

'What do you think John will buy?'

That is why in this section wh-extraction is tested in its most natural environment, analogous to that presented in (ii).

${ }^{22}$ Extraction of the entire DP from either the pre- or post-copula position in to być clauses is banned, as confirmed by (i) and (ii) below: 
Example (61a) shows that it is possible to move a wh-phrase from within the second DP in an uninverted structure in Polish, while extraction from within the second DP in inverted clauses leads to ungrammaticality, as confirmed by (61b). Although the extraction facts in Polish seem to be similar to those in English and Italian, the account we would like to offer is different. We would like to suggest that $(61 \mathrm{~b})$ is unacceptable in Polish as it violates locality, since the wh-PP o czym 'about what' moves across the inverted DP przyczyna zamieszek 'the cause of riots', which occupies a left peripheral position, either Spec, $\mathrm{CP}$ or some other position within the split CP. This conclusion seems to be supported by the fact that the sentence in (61b) improves if the wh-phrase appears to the right of the inverted DP, as in (62).

(62) Jak myślisz przyczyna zamieszek o czym to był artykuł?

what you-think cause of.riots about what TO was article

'*What do you think the cause of riots was an article about?'

Sentence (62) is grammatical and it seems to resemble frequent cases of wh-extraction co-occurring with topicalisation, as in (63), taken from Willim $(1989,108)$.

(63) Jana kto uderzył?

John-acc who hit

'Who hit John?'

(62) is grammatical for the same reason as (63), the topicalised phrase occupies Spec, TopP, whereas the wh-phrase lands below it in Spec, FocP, and consequently, there is no locality violation found in $(61 \mathrm{~b})$, as the wh-phrase does not move across the topic, the way it does in $(61 \mathrm{~b}){ }^{23}$

(i) *Jak myślisz $\mathrm{co}_{i} \quad t_{i}$ to była przyczyna zamieszek?

what you-think what TO was cause of-riots

'What do you think was the cause of riots?'

(ii) *Jak myślisz $\mathrm{co}_{i}$ artykuł o strajku to było $t_{i}$ ?

what you-think what article about strike TO was

'*What do you think an article about the strike was?'

${ }^{23}$ Sentence (i) below is grammatical even though kto 'who' appears to the left of the DP Jana 'John', but in this case the DP has undergone scrambling not topicalisation. 
Similar observations can be made in relation to simple być structures, as in (64), where extraction out the second DP in the inverted sentence is illicit, as shown in (65), but its status improves considerably if the extracted element appears to the right of the inverted DP as in (66).

(64) Przyczyną zamieszek był artykuł o strajku. cause-3.sg.fem.instr of-riots was-3sg.masc article-3sg.masc.nom about strike 'The cause of riots was an article about the strike.' inverted

(65) *Jak myślisz o $\quad \operatorname{czym}_{i}$ przyczyną zamieszek był artykuł $t_{i}$ ? what you-think about what cause-instr of-riots was article-nom

'*What do you think the cause of riots was an article about?'

(66) Jak myślisz przyczyną zamieszek o czym $_{\mathrm{i}}$ był artykuł $t_{i}$ ? what you-think cause-instr of-riots about what was article-nom '*What do you think the cause of riots was an article about?'

In sentences like (64) it is certainly the second DP which is the subject as it is marked for nominative and it determines concord with the verb. However, the unacceptability of (65) cannot be accounted for by appealing to extraction from within a subject, as in Polish this type of extraction produces only mild degradation. This is illustrated in (67) below.

(67) ${ }^{?} \mathrm{O} \quad \operatorname{kim}_{i}$ opowieść $t_{i}$ tak cię rozśmieszyła?

about whom story so-much you made-laugh

'*Who the story about made you laugh so much?'

(Willim 1989, 111)

Since (67), in which the $w h$-phrase has been moved from within the subject DP is only mildly deviant, the strong unacceptability of (65) cannot be explained by making recourse to the fact that a wh-phrase has been extracted from within a subject. Once again it seems that a locality violation brings about the unacceptability of (65), as the wh-element moves across a topic, i.e., the instrumental DP. The fact that inverted być clauses behave on a par with inverted to być clauses as regards extraction seems to

(i) Kto Jana uderzył?

who John hit

'Who hit John?'

The ways to distinguish topicalisation from scrambling in Polish are offered by Tajsner $(1998,119 f f)$, who notes that topics in Polish always come first in a sentence. 
support the analysis posited here, in which the inverted DP functions as a topic, not a subject, the way Moro (1997; 2006) and Mikkelsen (2005) claim for English inverse copula sentences.

The analysis of Polish inverted copula sentences offered in this section, relying on parallel probing by $\mathrm{T}$ and $\mathrm{C}$, is capable of accounting for the fact that no person match is required in sentences of this kind, as multiple Agree never affects the two DPs. It also correctly predicts that the verb in inverted copula clauses agrees with the second DP, which indeed functions as the subject. Finally, it offers an explanation for the otherwise mysterious wh-extraction facts, captured in (62), as the inverted DP is treated as a topic which can and frequently does co-occur with a whfocus phrase, placed to its right. All in all, inverted copula sentences do not seem to constitute any counterexamples for the analysis offered in this paper.

\section{Conclusion}

The paper has aimed at providing a uniform analysis of two apparently unrelated agreement patterns found in to być clauses in Polish. In the first pattern być always agrees with the following DP, not with the preceding one, whereas in the second pattern 1st and 2nd person pronouns are banned from occurring in clauses in which to links them with 3rd person DPs. Both patterns have been offered an analysis based on the current minimalist approach to the Person Case Constraint. This approach crucially relies on the application of multiple Agree as well as the assumption that in Polish, just like in other languages, $\mathrm{T}$ probes separately for person and number. It has been argued that in both patterns scrutinized, $\mathrm{T}$ probes the first DP for person and the second one for number and gender, which explains agreement with the second element in the first pattern. It is the first DP that values the person feature of $T$ and therefore if the first DP is 1st or 2nd person, it values the person feature of $\mathrm{T}$ as 1 st or 2nd, and this gives rise to a person clash if the second DP is marked for 3rd person, which accounts for the second pattern.

It has been argued that the fact that the PCC is inoperative in the Polish double object construction does not pose any threat for the PCC based analysis of the agreement patterns attested in copular clauses, as the double object construction does not involve multiple Agree, unlike the copular constructions discussed here. Following Citko (2011), it has been proposed that each object DP in the double object construction has 
its case valued by a different head, an accusative one by a little $\mathrm{v}$, and the dative one by a new functional projection, the so-called little applicative head. Since the two objects in this type of structure do not undergo Agree with the same probe, the lack of PCC effects is not surprising, but, on the contrary, it represents the expected scenario.

Two cases have been mentioned in which a person mismatch is tolerated in Polish to być sentences and which, at first glance, constitute a problem for the analysis outlined in the paper. After a close scrutiny the first case has been treated as containing an equative structure, not analyzable in the same way as predicative structures discussed in the paper. In fact, equatives have been treated as bare small clauses, along the lines proposed for Russian by Pereltsvaig (2001; 2008) and for English and Italian by Moro (2006). It has been suggested that there is no multiple Agree in equatives due to the fact that the second DP moves (is internally merged) to provide a label for the bare small clause and hence becomes closer to the probe $\mathrm{T}$, which makes the other DP inaccessible to $\mathrm{T}$. In the second case of person mismatch, the one with the inverted DP, parallel probing by $\mathrm{T}$ and $\mathrm{C}$ has been advocated, whereby the inverted DP comes to occupy Spec, CP and hence ceases to be a potential goal for $\mathrm{T}$. It has been shown that some facts relating to extraction support the left peripheral position of the inverted DP. Consequently, in inverted structures there is no multiple Agree and no person mismatch arises.

\section{References}

Adger, David-Gillian Ramchand 2003. Predication and equation. In: Linguistic Inquiry $34: 325-60$.

Akmajian, Adrian 1979. On deriving cleft sentences from pseudocleft sentences. In: Linguistic Inquiry 1:149-68.

Albizu, Pablo 1997. Generalized Person-Case constraint: A case for syntax-driven inflectional morphology. In: Amaya Mendikoetxea - Myriam Uribe-Etxebarria (eds): Theoretical issues at the morphology-syntax interface, 1-33. Universidad del País Vasco, Bilbao \& San Sebastián.

Anagnostopoulou, Elena 2003. The syntax of ditransitives: Evidence from clitics. Mouton de Gruyter, Berlin \& New York.

Anagnostopoulou, Elena 2005. Strong and weak person restrictions. A feature checking analysis. In: Lorie Heggie - Francisco Ordóñez (eds): Clitic and affix combinations, 199-235. John Benjamins, Amsterdam \& Philadelphia.

Béjar, Susana-Milan Rezac 2003. Person licensing and the derivation of PCC effects. In: Ana Teresa Pérez-Leroux-Yves Roberge (eds): Romance linguistics: Theory and acquisition. Selected papers from the 32nd Linguistic Symposium 
on Romance Languages (LSRL) Toronto, April 2002, 49-62. John Benjamins, Amsterdam \& Philadelphia.

Boeckx, Cedric 2000. Quirky agreement. In: Studia Linguistica 54:354-80.

Bogusławski, Andrzej 2002. To jest/das ist unteilbare Spracheinzeiten? Doch! In: Die Welt der Slaven $67: 131-54,251-74$.

Bondaruk, Anna 2010. To as a verb or as a pronoun. The case of Polish copular constructions. In: Eugeniusz Cyran-Bogdan Szymanek (eds): Verb structures. Between phonology and morphosyntax, 53-73. Wydawnictwo Katolickiego Uniwersytetu Lubelskiego, Lublin.

Bondaruk, Anna to appear. Are there any PCC effects in the Polish double object construction? In: Anna Bloch-Rozmej-Maria Bloch-Trojnar (eds): Modules and interfaces, Wydawnictwo Katolickiego Uniwersytetu Lubelskiego, Lublin.

Bonet, Eulàlia 1991. Morphology after syntax: Pronominal clitics in Romance. Doctoral dissertation, MIT.

Bonet, Eulàlia 1994. The Person-Case Constraint: A morphological approach. In: Heidi Harley-Colin Phillips (eds): The morphology-syntax connection (MITWPL 22), 33-52. MIT Press, Cambridge MA.

Chomsky, Noam 2000. Minimalist inquiries: The framework. In: Roger Martin-David Michaels - Juan Uriagereka (eds): Step by step: Essays on minimalist syntax in honor of Howard Lasnik, 89-155. MIT Press, Cambridge MA.

Chomsky, Noam 2001. Derivation by phase. In: Michael Kenstowicz (ed.): Ken Hale: A life in language, 1-52. MIT Press, Cambridge MA.

Chomsky, Noam 2008. On phases. In: Robert Freidin-Carlos P. Otero-Maria Luisa Zubizarreta (eds): Foundational issues in linguistic theory. Essays in honor of Jean-Roger Vergnaud, 134-66. MIT Press, Cambridge MA.

Citko, Barbara 2008. Small clauses reconsidered: Not so small and not all alike. In: Lingua 118:261-95.

Citko, Barbara 2011. Symmetry in syntax. Merge, Move and labels. Cambridge University Press, New York.

Dikken, Marcel den 2006. Relators and linkers: The syntax of predication, predicate inversion, and the copula. MIT Press, Cambridge MA.

Franks, Steven - Tracy Holloway King 2000. Handbook of Slavic clitics. Oxford University Press, New York.

Haspelmath, Martin 2004. Explaining the ditransitive Person Case constraint: A usagebased approach. Constructions 2. Ms. www.constructions-online.de/articles/35.

Heggie, Lorie A. 1988. The syntax of copular structures. Doctoral dissertation, University of Southern California, Los Angeles.

Hentschel, Gerd 2001. On the perspectivisation of noun phrases in copula sentences, mainly in Polish: (Y) to (jest) X and similar phenomena. In: Viktor S. ChrakovskijMaciej Grochowski-Gerd Hentschel (eds): Studies on the syntax and semantics of Slavonic languages, 161-213. Bibliotheks- und Informationssystem der Universität Oldenburg, Oldenburg.

Heycock, Caroline-Anthony Kroch 1999. Pseudocleft connectedness: Implications for the LF interface level. In: Linguistic Inquiry 30:365-98.

Acta Linguistica Hungarica 59, 2012 
Hiraiwa, Ken 2002. Multiple Agree. Paper presented at the 25th GLOW Workshop: Tools in Linguistic Theory, Utrecht Institute of Linguistics.

Kayne, Richard S. 1994. The antisymmetry of syntax. MIT Press, Cambridge MA.

Linde-Usiekniewicz, Jadwiga 2007. Small clauses reconsidered revisited: Not so small and not all alike, and far fewer. In: Lingua Posnaniensis 49:83-91.

Migdalski, Krzysztof 2006. The syntax of compound tenses in Slavic. LOT Publications, Utrecht.

Mikkelsen, Line 2005. Copular clauses. Specification, predication and equation. John Benjamins, Amsterdam \& Philadelphia.

Moro, Andrea 1997. The raising of predicates: Predicative noun phrases and the theory of clause structure. Cambridge University Press, Cambridge.

Moro, Andrea 2006. Some notes on unstable structures. Ms. Università Vita Salute San Raffaele.

Pereltsvaig, Asya 2001. On the nature of intra-clausal relations. Doctoral dissertation, McGill University.

Pereltsvaig, Asya 2008. Copular sentences in Russian. A theory of intra-clausal relations. Springer, New York.

Perlmutter, David 1971. Deep and surface structure constraints in syntax. Holt, Rinehart and Winston, New York.

Rezac, Milan 2008. The syntax of eccentric agreement: The Person Case Constraint and absolutive displacement in Basque. In: Natural Language and Linguistic Theory $26: 61-106$.

Rezac, Milan 2011. Phi-features and the modular architecture of language. Springer, Dordrecht.

Richards, Marc 2008. Defective Agree, Case alternations and the prominence of person. In: Marc Richards - Andrej L. Malchukov (eds): Linguitische Arbeits Berichte 86, 137-61. Universität Leipzig.

Richards, Norvin 2005. Person-Case effect in Tagalog and the nature of long-distance extraction. In: Jeffrey Heinz - Dimitris Ntelitheos (eds): Proceedings of the Twelfth Annual Conference of the Austronesian Formal Linguistics Association, UCLA Working Papers in Linguistics 12, 383-94. UCLA Department of Linguistics.

Rivero, Maria Luisa 2004. Spanish quirky subjects, person restrictions and the PersonCase Constraint. In: Linguistic Inquiry 35 : 494-502.

Rutkowski, Paweł 2006. From demonstratives to copulas: A cross-linguistic perspective and the case of Polish. In: Journal of Universal Language $7: 147-75$.

Slioussar, Natalia 2011. Russian and the EPP requirement in the Tense domain. In: Lingua $121: 2048-68$.

Sturgeon, Anne-Boris Harizanow-Maria Polinsky-Ekaterina Kravtchenko-Carlos Gómez Gallo-Lucie Medová-Václav Koula 2010. Revisiting the Person Case Constraint in Czech. Ms. (www.fas.harvard.edu/ herpro/files/Strugeon.etal.FASL.PCC.handout.pdf)

Tajsner, Przemysław 1998. Minimalism and functional thematization. Motivex, Poznań. 
Willim, Ewa 1989. On word order: A government-binding study of English and Polish. Wydawnictwo Uniwersytetu Jagiellońskiego, Kraków.

Wiśniewski, Marek 1990. Formalnogramatyczny opis leksemów to. 2. Słowo to w funkcji spójnika, partykuły, czasownika niewłaściwego. In: Acta Universitatis Nicolai Copernici 192:91-119.

Witkoś, Jacek 1998. The syntax of clitics. Steps towards a minimalist account. Motivex, Poznań. 